\title{
Deoxyribonucleic Acid Relatedness Among Actinobacillus actinomycetemcomitans, Haemophilus aphrophilus, and Other Actinobacillus Species
}

\author{
ALAN L. COYKENDALL, ${ }^{1 *}$ JANE SETTERFIELD, ${ }^{1}$ AND JøRGEN SLOTS ${ }^{2}$ \\ Department of Oral Diagnosis, School of Dental Medicine, University of Connecticut Health Center, \\ Farmington, Connecticut 06032, ${ }^{1}$ and Department of Oral Biology and Periodontal Disease Clinical Research \\ Center, State University of New York at Buffalo, Buffalo, New York $14226^{2}$
}

\begin{abstract}
The relationship among 22 strains of Actinobacillus actinomycetemcomitans, 3 strains of Haemophilus aphrophilus, 1 reference strain of Actinobacillus lignieresii, and the type strain of Actinobacillus equuli were assessed by deoxyribonucleic acid (DNA)-DNA hybridizations on membrane filters. We found that the $A$. actinomycetemcomitans strains formed a homogeneous group that was distinct from $H$. aphrophilus and the other Actinobacillus species. There was about $40 \%$ hybridization between $H$. aphrophilus DNA and $A$. actinomycetemcomitans DNA, indicating some similarity, but $A$. lignieresii and $A$. equuli DNAs hybridized much less (never more than 20\%) with $A$. actinomycetemcomitans DNA.
\end{abstract}

Interest in Actinobacillus actinomycetemcomitans has increased recently since this bacterium has been found to be associated with human periodontal disease, especially those forms of periodontal disease that seem to progress rapidly (15). This organism can also be found in the mouths of subjects without periodontal disease. In addition, $\boldsymbol{A}$. actinomycetemcomitans is frequently associated with actinomycosis (15).

Oral isolates of this species show some degree of heterogeneity in serology (13) and sugar fermentation patterns (12), although the overall characteristics of 136 strains were recently shown to be quite uniform (14). The same study pointed out the characteristics by which $A$. actinomycetemcomitans can be differentiated from Haemophilus aphrophilus, an organism that it closely resembles. Calhoon et al. showed that soluble proteins extracted from 20 strains of A. actinomycetemcomitans formed similar patterns when they were separated electrophoretically on polyacrylamide gels and that the protein patterns of $\boldsymbol{H}$. aphrophilus and various Actinobacillus species were distinct from each other and from the protein pattern of $A$. actinomycetemcomitans (1). The purposes of this study were to determine deoxyribonucleic acid (DNA.) base sequence homologies among several $A$. actinomycetemcomitans strains and to compare the DNA base sequence of $A$. actinomycetemcomitans with the DNA base sequences of $H$. aphrophilus, Actinobacillus lignieresii, and Actinobacillus equuli.

A total of 27 bacterial strains from the collection of J. Slots were used in this study (Table 1). Cultures were maintained on blood agar which contained casein and soy digests (Trypticase soy agar; BBL Microbiology Systems, Cockeysville, Md.), $0.1 \%$ yeast extract, and $10 \%(\mathrm{vol} / \mathrm{vol})$ sheep blood.

We found that it was convenient to grow and maintain cultures in an anaerobic chamber with an atmosphere containing $85 \% \mathrm{~N}_{2}, 10 \% \mathrm{H}_{2}$, and $5 \% \mathrm{CO}_{2}$. Broth cultures were grown in a medium which contained $0.5 \%$ yeast extract, $1.5 \%$ casein peptone, $0.75 \%$ glucose, $0.25 \% \mathrm{NaCl}, 0.075 \% \mathrm{~L}$ cysteine, and $0.05 \%$ sodium thioglycolate. After this broth was autoclaved, it was supplemented with $4 \mathrm{~g}$ of filter-sterilized $\mathrm{NaHCO}_{3}$ per liter. For production of radioactive DNA, the medium was supplemented with $1 \mathrm{mCi}$ of [methyl$\left.{ }^{3} \mathrm{H}\right]$ thymidine per $\mathrm{ml}$.

The biochemical reactions of $A$. actinomycetemcomitans and $H$. aphrophilus strains were determined by using commercially prepared test reagents (API-20A; Analytab Products, Plainview, N.Y.).

To prepare DNA, 1 liter of the broth described above was inoculated with $10 \mathrm{ml}$ of a fresh culture and incubated for $24 \mathrm{~h}$ at $37^{\circ} \mathrm{C}$. A sample was streaked onto blood agar to check for purity; then the culture was centrifuged, washed, and suspended in $25 \mathrm{ml}$ of $1 \times \operatorname{SSC}(0.15 \mathrm{M} \mathrm{NaCl}$ plus $0.015 \mathrm{M}$ sodium citrate, $\mathrm{pH}$ 8.0). After 1 drop of the washed cells was Gram stained, the cells were lysed with sodium dodecyl sulfate (1 $\mathrm{ml}$ of a $25 \%$ [wt/vol] solution), and the suspension was held at $60^{\circ} \mathrm{C}$ for $30 \mathrm{~min}$. The material was cooled to $35^{\circ} \mathrm{C}$ and then treated with about $50 \mathrm{mg}$ of protease (type XIV; Sigma Chemical Co., St. Louis, Mo.). The DNA was purified by phenol and chloroform extractions, treatment 
TABLE 1. Extent of DNA hybridization between $A$. actinomycetemcomitans and $\boldsymbol{H}$. aphrophilus strains $^{a}$

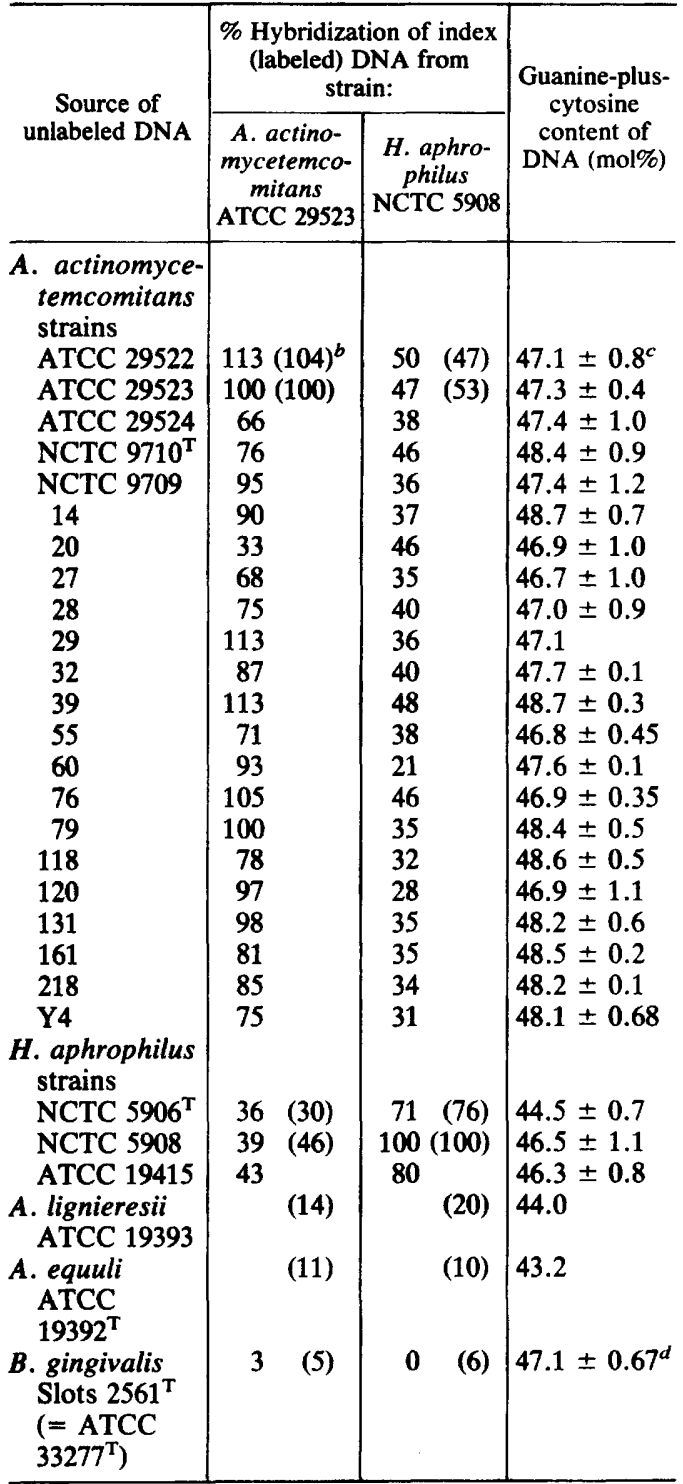

a Expressed as hybrid duplex formation compared with homologous duplex formation.

${ }^{b}$ The results of a second experiment are indicated in parentheses.

c Mean \pm standard deviation.

d Data from reference 3.

with ribonuclease for $30 \mathrm{~min}$ at $60^{\circ} \mathrm{C}$ and then for $30 \mathrm{~min}$ at $35^{\circ} \mathrm{C}$, and precipitation with ethanol, essentially by the method of Marmur (9).

The base compositions of the DNA preparations were determined by thermal denaturation in $1 \times$ SSC (10). The temperature of each sample was automatically raised $0.5^{\circ} \mathrm{C} / \mathrm{min}$ with an elec- trically heated cuvette holder (model 2527 thermoprogrammer; Gilford Instrument Laboratories, Oberlin, Ohio).

DNA hybridizations were carried out by using the membrane filter method of Legault-Démare et al. (8), as described elsewhere (3). The renaturation incubation temperature used was $51^{\circ} \mathrm{C}$ and was determined from the formula of De Ley and Tijtgat (5). Each experiment included a homologous control and a negative control. The homologous control reassociation was the reassociation of a labeled DNA with unlabeled DNA of the same bacterial strain. The degree of reassociation in the homologous control, as measured by liquid scintillation counting of the $\left[{ }^{3} \mathrm{H}\right] \mathrm{DNA}$, was considered to be $100 \%$, and the degrees of interstrain reassociation were expressed as percentages of the control value. The negative control reassociation was the reassociation between a labeled DNA and the DNA of the clearly unrelated organism Bacteroides gingivalis Slots $2561^{\mathrm{T}}$ (type strain).

Biochemical tests of the A. actinomycetemcomitans and $\boldsymbol{H}$. haemophilus strains produced results that were consistent with a previous description of the phenotypic traits of these species (13).

The DNA base compositions of the various strains are shown in Table 1. The DNAs of $A$. actinomycetemcomitans strains contained between 46.7 and $48.7 \mathrm{~mol} \%$ guanine plus cytosine. The $\boldsymbol{H}$. aphrophilus strains had slightly lower guanine-plus-cytosine contents. $A$. lignieresii and $A$. equuli had clearly different guanine-plus-cytosine contents than $A$. actinomycetemcomitans (44.0 and $43.2 \mathrm{~mol} \%$, respectively).

Hybridization experiments indicated considerable base sequence similarities among the DNAs of 20 A. actinomycetemcomitans strains. DNAs from these strains formed hybrid reassociation products with strain ATCC 29523 $\left[{ }^{3} \mathrm{H}\right] \mathrm{DNA}$ to a level greater than $65 \%$ of the homologous control reassociation.

The DNAs of 17 strains hybridized more than 74\%. One strain (strain 20) appeared to be completely unrelated to A. actinomycetemcomitans. This strain did not differ in any other way from the other strains, and we suspect that the culture from which strain 20 DNA was extracted was contaminated or mislabeled or that the DNA had deteriorated. In contrast, $H$. aphrophilus DNA hybridized only about $40 \%$ with $A$. actinomycetemcomitans $\left[{ }^{3} \mathrm{H}\right] \mathrm{DNA}$. The reciprocal experiment, in which the labeled DNA was from H. aphrophilus, gave the expected reciprocal results (homology among $\boldsymbol{H}$. aphrophilus strains and much lower degree of relatedness to A. actinomycetemcomitans strains).

A second pair of experiments (Table 1) confirmed the relationship between A. actinomyce- 
temcomitans and $\boldsymbol{H}$. aphrophilus and revealed that neither of these species is closely related to A. equuli or A. lignieresii.

The results of our experiments, together with the results of biochemical studies, strengthen the view that $A$. actinomycetemcomitans is a species distinct from $H$. aphrophilus. Although the reassociation values for some strains were less than $75 \%$, these strains were even less related to $\boldsymbol{H}$. aphrophilus. For example, strain ATCC 29524 DNA reassociated only $66 \%$ with strain ATCC 29523 DNA, but it reassociated only $38 \%$ with $H$. aphrophilus NCTC 5908 DNA. Interestingly, the degrees of relationship between $A$. actinomycetemcomitans and the other Actinobacillus species were even lower. Kilian has pointed out that $A$. actinomycetemcomitans is more similar to $H$. aphrophilus than to A. lignieresii, the type species of Actinobacillus, and suggested that $A$. actinomycetemcomitans could be placed in the genus Haemophilus (7). (H. aphrophilus itself is not a true Haemophilus species in some respects; for a detailed discussion of Haemophilus taxonomy, see reference 7.) Our results are consistent with this. A. actinomycetemcomitans DNA did not hybridize appreciably with either $A$. lignieresii or $A$. equuli DNA, but it did hybridize at levels of $40 \pm 10 \%$ with $H$. aphrophilus DNA. On the other hand, Pohl (11), who used the renaturation rate method (4) of measuring DNA hybridization, found that $\boldsymbol{A}$. actinomycetemcomitans was somewhat more related to $A$. lignieresii than to $H$. aphrophilus (40 versus $30 \%$ ).

Since the method which we used compares the hybridization of a labeled DNA with several other DNAs in the same experiment and because we used labeled DNAs from both $A$. actinomycetemcomitans and $H$. aphrophilus, we believe that the consistently higher level of hybridization of $A$. actinomycetemcomitans DNA with $H$. aphrophilus DNA indicates a significantly higher degree of relationship between these two species than between $A$. actinomycetemcomitans and the other Actinobacillus species. It should be borne in mind that hybridization values of $40 \%$ do not necessarily indicate $40 \%$ base sequence homology since at such low levels of reassociation the DNA duplexes may contain nonspecific base pairings $(2,6)$.

We think that our results support the conclusion that $A$. actinomycetemcomitans is a distinct species which is genetically somewhat related to $H$. aphrophilus and minimally related to other Actinobacillus species.

This investigation was supported by Public Health Service grant DE-04721 from the National Institute of Dental Research.

\section{LITERATURE CITED}

1. Calhoon, D. A., W. R. Mayberry, and J. Slots. 1981. Cellular fatty acid and soluble protein composition of Actinobacillus actinomycetemcomitans and related organisms. J. Clin. Microbiol. 14:376-382.

2. Coykendall, A. L. 1971. Genetic heterogeneity in Streptococcus mutans. J. Bacteriol. 106:192-196.

3. Coykendall, A. L., F. Kaczmarek, and J. Slots. 1980. Genetic heterogeneity in Bacteroides asaccharolyticus (Holdeman and Moore 1970) Finegold and Barnes 1977 (Approved Lists 1980) and proposal of Bacteroides gingivalis sp. nov. and Bacteroides macacae (Slots and Genco) comb. nov. Int. J. Syst. Bacteriol. 30:559-564.

4. De Ley, J., H. Cattoir, and A. Reynaerts. 1970. The quantitative measurement of DNA hybridization from renaturation rates. Eur. J. Biochem. 12:133-142.

5. De Ley, J., and R. Tijtgat. 1970. Evaluation of membrane filters for DNA-DNA hybridization. Antonie van Leeuwenhoek J. Microbiol. Serol. 36:461-474.

6. Johnson, J. L., and E. J. Ordal. 1968. Deoxyribonucleic acid homology in bacterial taxonomy: effect of incubation temperature on reaction specificity. J. Bacteriol. 95:893900.

7. Kilian, M. 1976. A taxonomic study of the genus Haemophilus, with the proposal of a new species. J. Gen. Microbiol. 93:9-62.

8. Legault-Démare, J., B. Desseaux, J. Heyman, S. Seror, and G. P. Ress. 1967. Studies on hybrid molecules of nucleic acids. I. DNA-DNA hybrids on nitrocellulose filters. Biochem. Biophys. Res. Commun. 28:550-557.

9. Marmur, J. 1961. A procedure for the isolation of deoxyribonucleic acid from microorganisms. J. Mol. Biol. 3:208 218.

10. Marmur, J., and P. Doty. 1962. Determination of the base composition of deoxyribonucleic acid from its thermal denaturation temperature. J. Mol. Biol. 5:109-118.

11. Pohl, S. 1981. DNA relatedness among members of Haemophilus, Pasteurella and Actinobacillus, p. 245-253. In M. Kilian, W. Frederiksen, and E. L. Biberstein (ed.), Haemophilus, Pasteurella and Actinobacillus. Academic Press, Inc., New York.

12. Pulverer, G., and H. L. Ko. 1970. Actinobacillus actinomycetemcomitans: fermentative capabilities of 140 strains. Appl. Microbiol. 20:693-695.

13. Pulverer, G., and H. L. Ko. 1972. Serological studies on Actinobacillus actinomycetemcomitans. Appl. Microbiol. 23:207-210.

14. Slots, J. 1982. Salient biochemical characters of Actinobacillus actinomycetemcomitans. Arch. Microbiol. 131:6067.

15. Slots, J., H. S. Reynolds, and R. J. Genco. 1980. Actinobacillus actinomycetemcomitans in human periodontal disease: a cross-sectional microbiological investigation. Infect. Immun. 29:1013-1020. 